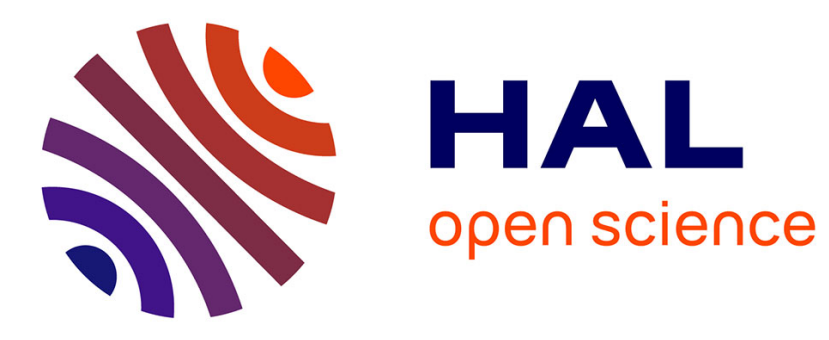

\title{
Interactions between ferrite recrystallization and austenite formation in high-strength steels
}

Abdelahad Chbihi, David Barbier, Lionel Germain, Alain Hazotte, Mohamed

Gouné

\section{- To cite this version:}

Abdelahad Chbihi, David Barbier, Lionel Germain, Alain Hazotte, Mohamed Gouné. Interactions between ferrite recrystallization and austenite formation in high-strength steels. Journal of Materials Science, 2014, 49 (10), pp.3608-3621. 10.1007/s10853-014-8029-2 . hal-00974406

\section{HAL Id: hal-00974406 https://hal.science/hal-00974406}

Submitted on 28 Jan 2021

HAL is a multi-disciplinary open access archive for the deposit and dissemination of scientific research documents, whether they are published or not. The documents may come from teaching and research institutions in France or abroad, or from public or private research centers.
L'archive ouverte pluridisciplinaire HAL, est destinée au dépôt et à la diffusion de documents scientifiques de niveau recherche, publiés ou non, émanant des établissements d'enseignement et de recherche français ou étrangers, des laboratoires publics ou privés. 


\title{
Interactions between ferrite recrystallization and austenite formation in high-strength steels
}

\author{
A. Chbihi · D. Barbier $\cdot$ L. Germain • \\ A. Hazotte $\cdot$ M. Gouné
}

\begin{abstract}
Using both experimental and modeling approaches, we give some clarifications regarding the mechanisms of interaction between ferrite recrystallization and austenite formation in cold-rolled high-strength steels. Using different thermal paths, we show that ferrite recrystallization and austenite formation can be strongly interdependent. The nature of the interaction (weak or strong) affects significantly the austenite formation and the resulting microstructure. We show that the kinetics of austenite formation depends intrinsically on both heating rates and the extent of ferrite recrystallization. An unexpected behavior of austenite growth was also seen at high heating rates. A possible explanation is presented based on the nature of the local equilibrium at the ferrite-austenite interface. The microstructure is more heterogeneous and anisotropic when both austenite formation and ferrite recrystallization overlap. A mechanism of microstructural formation is proposed, and this is supported by 2D simulations' images.
\end{abstract}

A. Chbihi · D. Barbier
Arcelormittal Maizières Research SA, Voie Romaine, BP 30302,
57283 Maizières les Metz, France

A. Chbihi - L. Germain - A. Hazotte

Laboratoire d'Étude des Microstructures et de Mécanique des Matériaux (LEM3), UMR CNRS 7239, Université de Lorraine, Île du Saulcy, 57045 METZ Cedex 1, France

L. Germain · A. Hazotte

Laboratory of Excellence on Design of Alloy Metals for lowmAss Structures ('LabEx DAMAS'), Université de Lorraine, METZ Cedex 1, France

M. Gouné $(\bowtie)$

ICMCB Bordeaux - UPR CNRS 9048I, 87 Avenue du Docteur Schweitzer, 33608 Pessac, France

e-mail: mm.goune@gmail.com

\section{Introduction}

The need to improve fuel efficiency and safety is driving a high and growing demand for high-strength steels in the automotive industry. The potential of weight reduction directly depends on the mechanical properties. These are, in turn, controlled by the microstructure:volume fraction, morphology, size, and distribution of constituents.

One of the typical processing steps used in the production of cold-rolled high-strength steels is continuous annealing in a galvanizing line [1]. In this process, the production of a ferrite $(\alpha)$-austenite $(\gamma)$ mixture is achieved by heating and soaking in the intercritical temperature range [2]. However, the effects of process parameters such as heating rate, annealing temperature, and holding time need to be understood to allow for optimal microstructural design [3]. Consequently, the formation of austenite in the intercritical region has received great attention [4-7]. Investigating austenite formation from an initial ferrite/ pearlite microstructure without any prior deformation, Speich et al. [8] observed four major transformation stages: (1) pearlite to austenite transformation, (2) austenite growth controlled by the carbon diffusion in austenite, (3) austenite growth controlled by the manganese diffusion in ferrite, and (4) final equilibrium via partitioning of $\mathrm{Mn}$ to the austenite. In this simple case, the rate for austenite growth is mainly controlled by the initial microstructure.

Austenite formation in cold-rolled high-strength steels is complicated by the recrystallization of ferrite that occurs during heating. Garcia and Deardo [9] and Yang et al. [10] investigated the effect of initial cold reduction on both the formation kinetics and morphology of austenite. They clearly showed that recrystallization of deformed ferrite and spheroidization of pearlite lamellae precedes austenite formation. Austenite formation was also seen to continue 
through the completion of ferrite recrystallization. Several authors confirmed that austenite formation in deformed low carbon steels differs radically from that without deformation [11-13]. Particularly, the microstructure is greatly affected by the prior cold reduction because it acts on both the nucleation and growth steps for austenite.

Two interactions can be distinguished: the "weak interaction," and the "strong interaction." In a weak interaction, the austenite is formed when the recrystallization is finished. In this case, only the recrystallized ferrite grain size influences the austenite growth. In a strong interaction, ferrite recrystallization and austenite formation occurs simultaneously.

Until recently, almost all the studies were concerned with the "weak interaction." However, a significant change of mechanical properties can be obtained in the case of a strong interaction [14]. The idea is to delay ferrite recrystallization to temperatures above the temperature at which austenite formation occurs. There are many ways to reach this goal. One is to add some microalloying elements, such as $\mathrm{Nb}$ or $\mathrm{B}$, which strongly delays ferrite recrystallization $[15,16]$. Another way is to use rapid heating [17-19]. Huang et al. [17] examined the effect of heating rate on microstructure for steels with chemistries typically used for dual-phase and TRIP steels. They observed significant effects of heating rate (from 1 to $100 \mathrm{~K} / \mathrm{s}$ ) on the volume fraction of austenite, its spatial distribution, and morphology. In particular, a much higher austenite volume fraction was measured for a given annealing time in the case of higher heating rates.

In terms of final properties, the role of heating rate is controversial. In some occasions, higher heating rates were noted to induce a heterogeneous distribution of coarse grains and phases elongated along the rolling direction [14, 17]. In this specific case, the mechanical properties exhibit a lower level of strength, despite the initially higher volume fraction of austenite. The behavior was explained by morphological and topological changes related to the interaction between ferrite recrystallization and austenite formation. In another work, Petrov et al. [18] recently suggested that in C-Mn-Si TRIP steel, austenite formation occurring in non-recrystallized ferrite during ultrafast heating $\left(<1000{ }^{\circ} \mathrm{C} / \mathrm{s}\right)$ leads to a refined and thus favorable, microstructure compared with conventional heating rates. These results point out that the formation of austenite depends on the progress of ferrite recrystallization. In return, recent works also suggest that ferrite recrystallization and subgrain growth in non-recrystallized ferrite can be inhibited by austenite transformation above the Ac1 temperature $[20,21]$. One of the proposed explanations is that the inhibition of recrystallization and interface migration could be due to a pinning effect induced by austenite formation at grain boundaries between deformed and recrystallized ferrites.
Table 1 Chemical composition of the material (wt $\%$ )

\begin{tabular}{llllll}
\hline $\mathrm{C}$ & $\mathrm{Mn}$ & $\mathrm{Si}$ & $\mathrm{P}$ & $\mathrm{S}$ & $\mathrm{Fe}$ \\
\hline 0.15 & 1.48 & 0.013 & 0.01 & $27 \mathrm{ppm}$ & bal. \\
\hline
\end{tabular}

Therefore, the overlap between ferrite recrystallization and austenite formation is a topic of interest. A better understanding of the mechanisms involved will allow for microstructural optimization and the development of new steels with improved mechanical properties. In the present paper, we propose to study, from an experimental and theoretical point of view, the involved mechanisms when ferrite recrystallization and austenite formation are strongly coupled. Using three heating paths, we give some clarifications and quantifications on how heating rate affects both the austenite transformation and ferrite recrystallization. In particular, we highlight that austenite formation is affected by ferrite recrystallization and vice versa.

\section{Materials and methods}

Materials and thermomechanical treatments

The nominal composition of the dual-phase steel studied in the present work is given in Table 1 .

The microstructure of the hot-rolled material contains bands of recrystallized ferrite grains ( $\sim 20 \mu \mathrm{m}$ in diameter) alternating with thinner bands of pearlites (the so-called bamboo structure). The hot-rolled sheets were subsequently cold rolled to $75 \%$ of reduction, leading to a final thickness of $0.7 \mathrm{~mm}$. Then, heat treatments were performed to characterize the interaction between austenite formation and ferrite recrystallization. They were performed on a DT 1000 thermal simulator from AdamelLhomargy, under argon gas, using samples with a section of $4 \times 0.7 \mathrm{~mm}^{2}$ and a length of about $12 \mathrm{~mm}$. The temperature was controlled by a type-K thermocouple spot welded to the center of the sample. Heating rates of 1 and $100{ }^{\circ} \mathrm{C} / \mathrm{s}$ were employed separately or combined. For some samples, heating was interrupted at different temperatures by helium quenching. The cooling rate was higher than $300{ }^{\circ} \mathrm{C} / \mathrm{s}$ to prevent any ferrite formation during cooling. In other experiments, some soaking steps were performed at $680,715,740$, and $780{ }^{\circ} \mathrm{C}$ for several durations between 0 and $1 \mathrm{~h}$, interrupted by helium quenching. Most of the results are referred to the temperature of $740{ }^{\circ} \mathrm{C}$, but some of the results obtained at other temperatures will be used to support our conclusions and to reinforce the discussion in Part 4. For the same purpose, a few experiments were also performed on a $\mathrm{Fe}-\mathrm{C}$ alloy, and these will also be presented in Part 4. 


\section{Microstructural and microtextural characterizations}

The microstructures of heat-treated samples were characterized by optical microscopy (Olympus PMG 3) and scanning electron microscopy (Jeol 6500-FEGSEM) equipped with a Nordlys-S camera (Oxford Instruments) for electron backscatter diffraction (EBSD) analyses. The choice of the observation zone is critical because it was shown that cold-rolled high-strength steels exhibit a heterogeneous through-thickness textural and microstructural evolutions [22]. In particular, it affects strongly both the grain size and the fraction of recrystallized ferrite. In this paper, the observations were always carried out at a quarter $(1 / 4)$ of the sheet thickness in the RD-ND plane ${ }^{1}$ for the reason that it classically gives an average representation of the microstructural feature. Dino etching was used to reveal the microstructure (it is composed of $140 \mathrm{ml}$ of distilled water, $100 \mathrm{ml}$ of $\mathrm{H}_{2} \mathrm{O}_{2}, 4 \mathrm{~g}$ of oxalic acid, $2 \mathrm{ml}$ of $\mathrm{H}_{2} \mathrm{SO}_{4}$, and $1.5 \mathrm{ml}$ of $\mathrm{HF}$ ). Metabisulfate etching was also used to discriminate martensite for measuring the volume fraction of austenite (martensite at room temperature) from optical micrographs. This volume fraction was determined using Aphelion software [23]. The data provided are the average values measured on ten micrographs $\left(120 \times 90 \mu \mathrm{m}^{2}\right)$; error bars indicate the confidence interval at $95 \%$.

Two methods were used to follow the evolution of ferrite recrystallization: Vickers hardness, and electron back scattered diffraction (EBSD). The former allowed for estimation of the volume fraction of recrystallized ferrite via the relative decrease of hardness between the asdeformed and the fully recrystallized states. Obviously, this method can only be used at less than the Ac1 temperature, whereas EBSD can be employed for higher temperatures when of austenite is present. Comparisons made below Ac1 showed that both methods give similar estimations [24]. Samples for EBSD mapping were prepared following conventional metallographic sample preparation finished by mechanical polishing with a suspension of $0.1-\mu \mathrm{m}$ diameter silica particles (OPS). The indexing rate was $70 \%$ in average, which can be explained by the small size of the microstructure and the presence of martensite and deformed ferrite. Some digital processing was made to the raw data, taking the precaution not to artificially grow the recrystallized ferrite (which is better indexed) into the other constituents of the microstructure. The separation of the different constituents in the microstructure (martensite, recrystallized ferrite, and deformed ferrite) was made manually. As the task is very tedious, preidentification was made using thresholding characteristic such as grain size,

\footnotetext{
1 The reference frame used in this work is RD: rolling direction, TD: transverse direction, and ND: direction normal to the plane of the sheet.
}

band contrast (BC), and/or band slope. No rule was found to be reproducible on every EBSD maps, and the parameters were adapted with the aim to minimize manual corrections for a correct identification. Manual corrections took advantage of extra information such as grain morphology and orientation relation.

\section{Modeling}

\section{DICTRA simulation of the austenite growth}

The presence of substitutional elements such as Mn in most steels affects both kinetics and equilibrium volume fraction of austenite. Indeed, contrary to the binary $\mathrm{Fe}-\mathrm{C}$ system, the compositions of $\mathrm{C}$ and $\mathrm{Mn}$ at the $\alpha / \gamma$-interface cannot be determined by the tie-line passing through the bulk alloy composition. The problem lies in the differences in diffusivities of the substitutional and interstitial solutes in both austenite and ferrite (e.g., which amount to roughly six orders of magnitude see $[25,26])$. The theory for austenite growth from cementite has been studied by many authors [5, 6, 27]. In all the cases considered, the local equilibrium (LE) condition was assumed $[25,26]$. This requires satisfying the mass balance equations applied to both the isothermal boundaries of the $\gamma+\alpha$ phase region and selection of an appropriate interfacial tie-line that depends on time and corresponds to a specific bulk composition. It is worth noting that this LE condition applied at the $\alpha / \gamma$ interface for the austenite growth does not correspond to the Local Equilibrium with Negligible Partition (LENP mode) classically used for ferrite growth [28].

In this paper, the ferrite-to-austenite phase transformation was simulated by DICTRA software using the TCFE5 and MOB2 databases. For the sake of simplicity, a planar geometry has been assumed for the growth of austenite. A cell size of $10 \mu \mathrm{m}$, which corresponds roughly to the recrystallized grain size, has been assumed, and the initial thickness of the austenite was chosen to be $0.4 \mu \mathrm{m}$. Furthermore, two different conditions at the moving $\alpha / \gamma$ interface were used: first, the LE condition discussed previously; and second, the para equilibrium (PE) condition introduced by Hultgren [29]. The latter is based on a constrained equilibrium for $\mathrm{C}$, and the other alloying elements are supposed to be unaffected by the interface motion.

\section{Generation of microstructures}

To help us analyze the microstructural evolution, a numerical simulation was developed for generating 2D images with a three-phase structure: grains of austenite, recrystallized ferrite, and deformed ferrite. Note that this simulation has no predictive purpose. It is used to evaluate 
the influence of different nucleation and growth parameters on the morphology of the final microstructures (see "Discussion" section). This dedicated program was written as an integrated command of the Aphelion software. Phase growth is modeled using discrete-image treatments mostly issued from mathematical morphology theory, especially isotropic geodesic dilations (see, for instance, Ref. [30] for a presentation of mathematical morphology concepts applied to image treatment). The main steps and assumptions of the algorithm are summarized in the following.

In the first step, nuclei of austenite and recrystallized ferrite are introduced as single pixels (picture elements) scattered in a discrete image with area $3000 \times 1000$ pixel $^{2}$, assumed initially to be constituted by $100 \%$ of deformed ferrite. All the nuclei are introduced at the same time, but different nucleation densities can be chosen for ferrite and austenite. Nuclei were dispersed either randomly (uniform spatial distribution) or by imposing a banded segregation to reproduce the influence of local manganese concentration on nucleation. In the latter case, the position of a possible seed is still drawn randomly, but nucleation is accepted or not by comparing a random number between 0 and 1 with the value of the function:

$F\left(y_{i}, S_{\phi}\right)=\frac{1}{2}+S_{\phi} \cdot \sin \left(2 \cdot \pi \cdot \frac{y_{i}-y_{\mathrm{r}}}{\lambda}\right)$,

where $y_{i}$ is the $y$ coordinate of the nucleus, $\lambda$ is the band periodicity, $y_{\mathrm{r}}$ is a random number which changes from an image to another to vary the band position, and $S_{\phi}$ is the segregation factor of the phase $\phi(\alpha$ or $\gamma)$. This process is similar to the one used in Ref. [31, 32] to simulate banded structures in ferrite-martensite steels. For reasons that will be explained in the following, segregation tendencies of ferrite and austenite were imposed with a shift of $1 / 2 \lambda$. That is, more favorable sites for nucleation of ferrite are less favorable for austenite and vice versa. The segregation factors $S_{\alpha}$ and $S_{\gamma}$ are varied independently of each other.

In the second step (growth), both austenite and recrystallized ferrite are imposed to grow isotropically, with the main difference that the latter can only grow at the detriment of deformed ferrite, whereas the former can overlay both types of ferrite. From a numerical point of view, growth is obtained by successive Euclidian dilations respecting the phase connexity, i.e., grain number [30]. The dilation rates can be different for each phase, but their ratio is limited by the discrete nature of the image. Note that a pixel/seed has no explicit size in this approach. Only differences in nucleation densities and/or growth rates of austenite and ferrite can indirectly lead to different final grain size ratios. Finally, the growths of ferrite and austenite are stopped once the final area fractions are attained. This model allows for the evaluation of the influence of six input parameters: the ratios between nucleation densities and growth rates of ferrite and austenite, the segregation factors of both phases, $S_{\alpha}$ and $S_{\gamma}$, and their final area fractions, $A_{\mathrm{A} \alpha}$ and $A_{\mathrm{A} \gamma}$. Although different output parameters can be obtained along the iterative process (phase amounts, grain size, elongation, etc.), they are not being reported in the present article. Only the final 2D microstructures are employed.

\section{Results}

Kinetics of ferrite recrystallization

The kinetics of ferrite recrystallization during heating before the formation of austenite (below $\mathrm{Ac}_{1}$ ) was determined as a function of heating rate (respectively, 1 and $100{ }^{\circ} \mathrm{C} / \mathrm{s}$ ). As expected, an increase of the heating rate leads to a significant delay of the ferrite recrystallization kinetics (Fig. 1a). At $1{ }^{\circ} \mathrm{C} / \mathrm{s}$, ferrite recrystallization starts at less than $600{ }^{\circ} \mathrm{C}$, whereas only a few percent is recrystallized at $650{ }^{\circ} \mathrm{C}$ for the $100{ }^{\circ} \mathrm{C} / \mathrm{s}$ heating rate. The Ac1 temperature $\left(\sim 730^{\circ} \mathrm{C}\right)$ is independent of the heating rate in the range of $\left[1-100{ }^{\circ} \mathrm{C} / \mathrm{s}\right]$. When $\mathrm{Ac} 1$ is reached, the ferrite is fully recrystallized at $1{ }^{\circ} \mathrm{C} / \mathrm{s}$, while $70 \%$ of the ferrite remains non-recrystallized at $100{ }^{\circ} \mathrm{C} / \mathrm{s}$.

The microstructures determined by EBSD before austenite formation at $720^{\circ} \mathrm{C}$ are presented in Fig. $1 \mathrm{~b}-\mathrm{d}$ as BC maps. When it is heated at $1{ }^{\circ} \mathrm{C} / \mathrm{s}$, the recrystallized ferrite microstructure consists of well-defined equiaxed grains having a mean diameter of $5 \mu \mathrm{m}$ (Fig. 1b). The darker bands correspond to the cementite-rich regions, less well indexed with the EBSD technique. The microstructure heated at $100{ }^{\circ} \mathrm{C} / \mathrm{s}$ is mostly (70 \%) composed of large deformed grains exhibiting substructures (Fig. 1b, c). The recrystallized ferrite grains $(30 \%)$ exhibit an equiaxed shape as observed in the magnified area (Fig. 1d).

Based on these results, a "weak interaction" is expected during intercritical annealing after heating at $1{ }^{\circ} \mathrm{C} / \mathrm{s}$. In this case, both processes (recrystallization and austenite formation) are decoupled and only the recrystallized ferrite grain size will influence the carbon diffusion length, and then the kinetics of austenite formation.

At $100{ }^{\circ} \mathrm{C} / \mathrm{s}$, ferrite recrystallization is delayed toward higher temperatures. In this case, both recrystallization and austenite processes overlap (called "strong interaction" hereafter).

Kinetics of austenite formation

The effects of initial heating rate on the kinetics of isothermal austenite formation at 740 and $780{ }^{\circ} \mathrm{C}$ have been examined. The results are given in Fig. 2, and their analysis leads to the following conclusion: the higher the heating rate, the faster the austenite formation kinetics. 

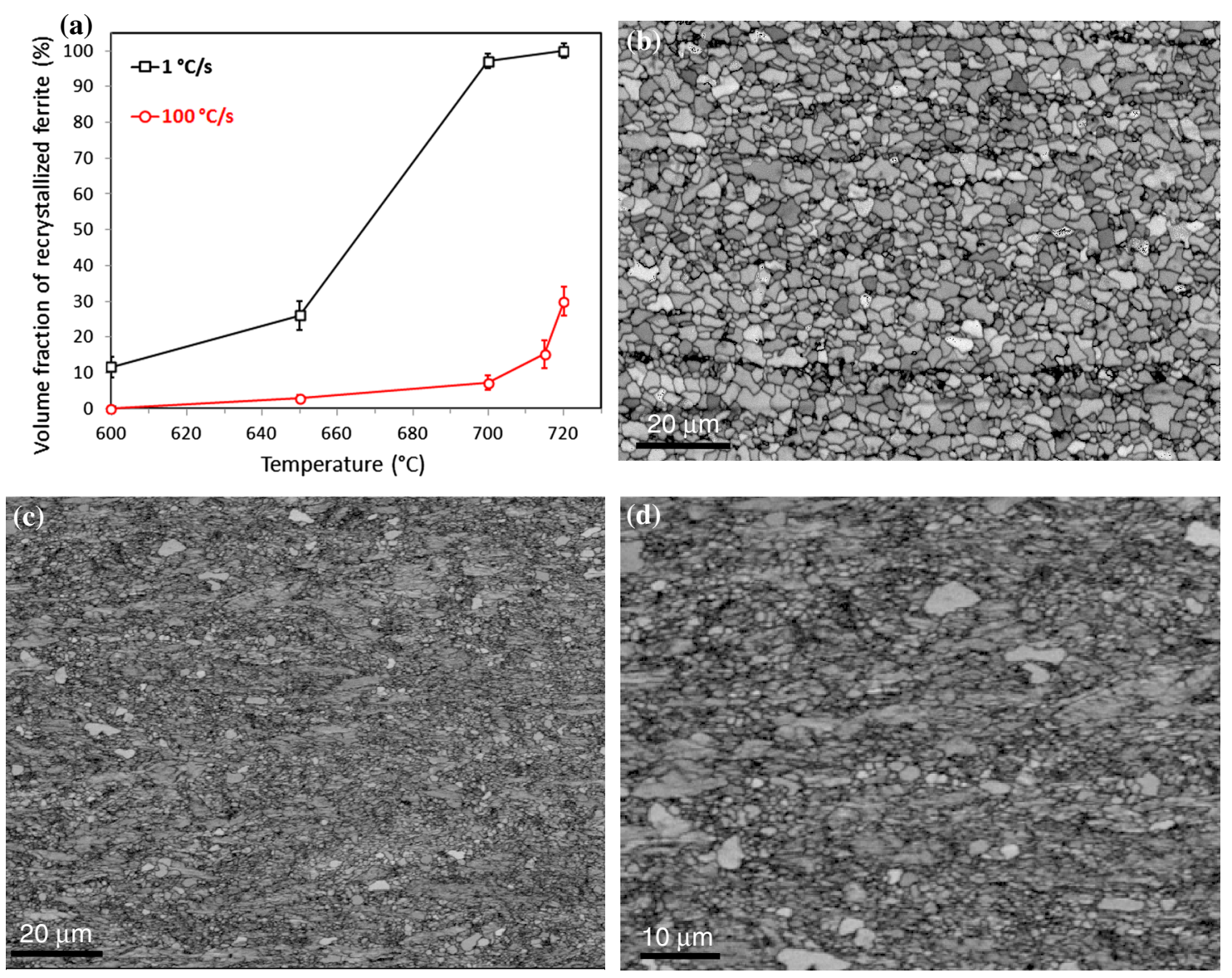

Fig. 1 a Evolution of the fraction of recrystallized ferrite during heating at different rates (obtained from hardness measurements), b "band contrast" (BC) map after quenching from $720{ }^{\circ} \mathrm{C}$ for $1{ }^{\circ} \mathrm{C} / \mathrm{s}$

heating rate, c $\mathrm{BC}$ map after quenching from $720{ }^{\circ} \mathrm{C}$ for $100{ }^{\circ} \mathrm{C} / \mathrm{s}$ heating rate, and $\mathbf{d}$ higher magnification of an area from (c)
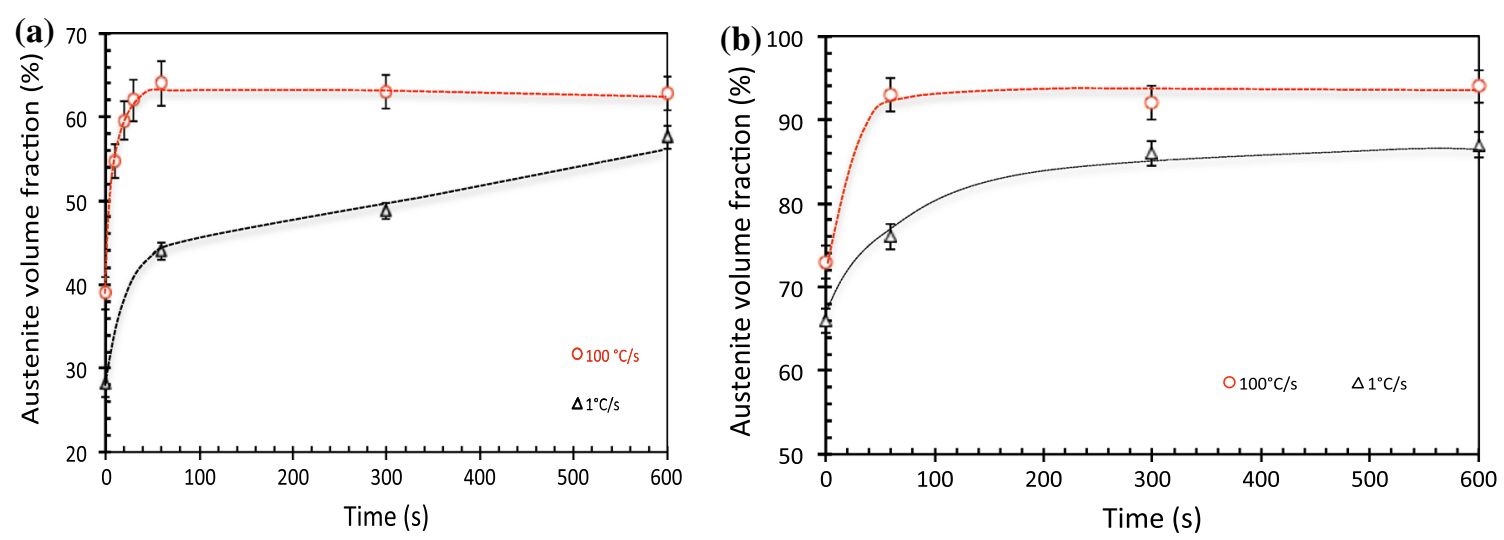

Fig. 2 Kinetics of austenite formation for two different heating rate $\left(1\right.$ and $\left.100{ }^{\circ} \mathrm{C} / \mathrm{s}\right)$ at $\mathbf{a} 740{ }^{\circ} \mathrm{C}$ and $\mathbf{b} 780{ }^{\circ} \mathrm{C}$

Unexpectedly, for all the considered temperatures, the initial austenite fraction is higher for the faster heating rate than the slower one. Furthermore, the maximum fraction of austenite is reached after a shorter time at $100{ }^{\circ} \mathrm{C} / \mathrm{s} \mathrm{com}$ pared to that at $1{ }^{\circ} \mathrm{C} / \mathrm{s}$. The sample with the higher heating rate displays a much higher austenite volume fraction for a given annealing time, and the volume fraction exceeds the full equilibrium fraction in the early stages of transformation. To our knowledge, this unexpected behavior was first mentioned by Huang et al. [17].

The mechanisms involved are very difficult to discern since many effects could be involved. For example, at a 

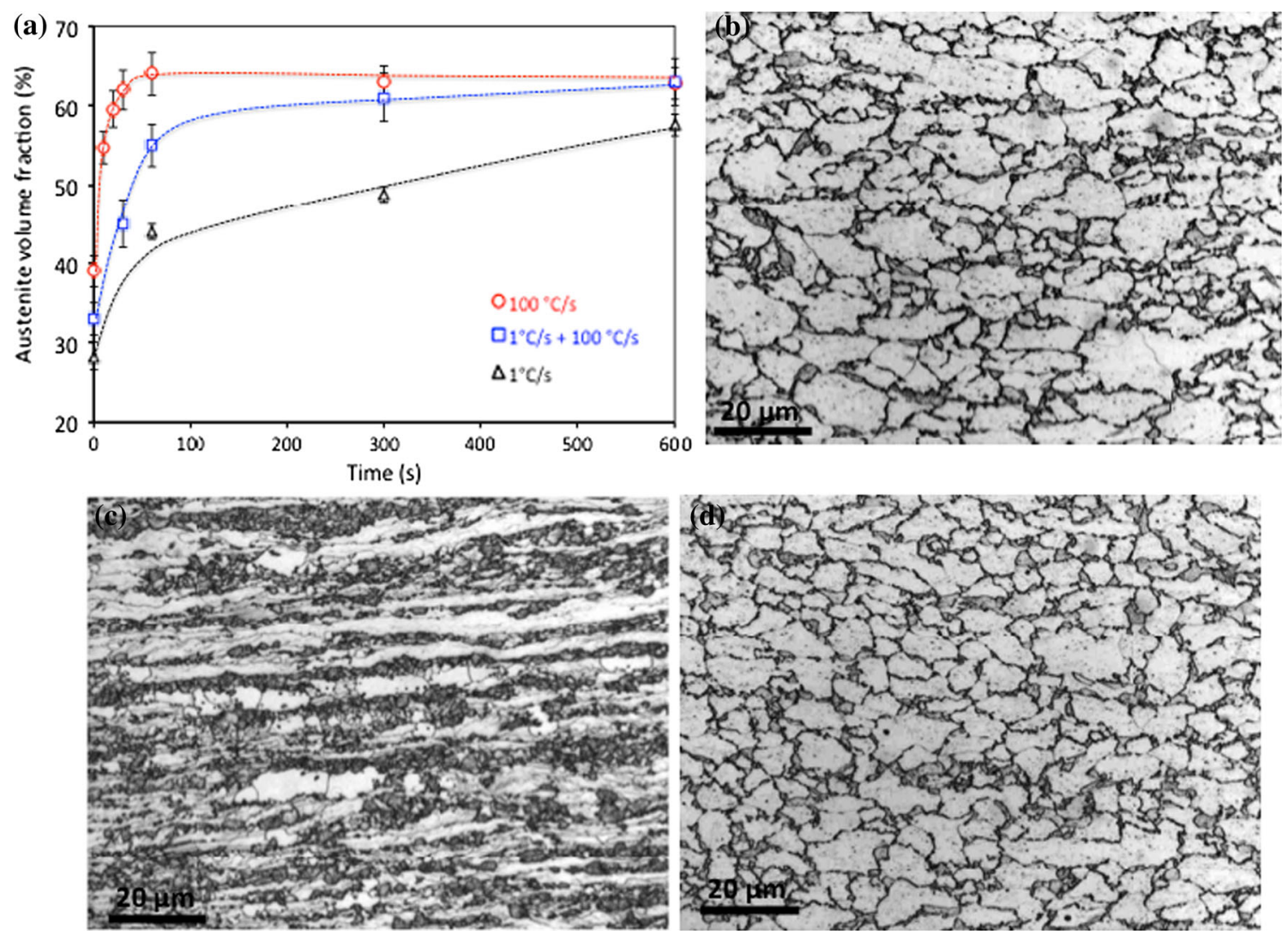

Fig. 3 a Kinetics of austenite formation for different conditions and comparison of microstructures at the same time (0 s) for the different heating paths, b $740{ }^{\circ} \mathrm{C}-1{ }^{\circ} \mathrm{C} / \mathrm{s}, \mathbf{c} 740{ }^{\circ} \mathrm{C}-100{ }^{\circ} \mathrm{C} / \mathrm{s}$, d $1{ }^{\circ} \mathrm{C} / \mathrm{s}$ up to $720{ }^{\circ} \mathrm{C}-100{ }^{\circ} \mathrm{C} / \mathrm{s}$ up to $740{ }^{\circ} \mathrm{C}$

high heating rate, the preservation of the defect structure in the non-recrystallized ferrite would provide additional nucleation sites for austenite. This could also enhance the diffusivities of elements such as carbon and manganese. To shed more light on the problem, we have decided to add a supplementary heating path combining a slow and a fast heating rate. It is characterized by a constant heating rate at $1{ }^{\circ} \mathrm{C} / \mathrm{s}$ from RT to $720{ }^{\circ} \mathrm{C}$ followed by a heating at $100{ }^{\circ} \mathrm{C} / \mathrm{s}$ from 720 to $740{ }^{\circ} \mathrm{C}$. This heating path was chosen because the microstructure obtained at $720{ }^{\circ} \mathrm{C}$ after heating at $1{ }^{\circ} \mathrm{C} / \mathrm{s}$ is fully recrystallized (see Fig. 1d). This enables the effects induced by the presence of non-recrystallized ferrite to be avoided. This latter path has been performed to decouple the intrinsic effects of heating rate on kinetics of austenite growth and the effects induced by the presence of nonrecrystallized ferrite.

Figure 3a shows the kinetics of austenite formation at $740{ }^{\circ} \mathrm{C}$ after the three different types of heating. Comparing both paths for which ferrite is completely recrystallized before austenite formation $\left(1{ }^{\circ} \mathrm{C} / \mathrm{s}\right.$ from RT to $740{ }^{\circ} \mathrm{C}$ and $1{ }^{\circ} \mathrm{C} / \mathrm{s}$ from RT to $720{ }^{\circ} \mathrm{C}$, followed by a heating rate of $100{ }^{\circ} \mathrm{C} / \mathrm{s}$ to $740{ }^{\circ} \mathrm{C}$ ), it is seen that the kinetics of austenite formation is much faster and austenite fraction is much higher for the second heating path. Therefore, it can be suspected that the kinetics of austenite growth depends intrinsically on the heating rate. When comparing all the heating paths (Fig. 3), the kinetics is even faster if starting with non-recrystallized ferrite $\left(100{ }^{\circ} \mathrm{C} / \mathrm{s}\right.$ from RT to $\left.740{ }^{\circ} \mathrm{C}\right)$. Therefore, it can be suspected that kinetics of austenite also depends on the recrystallization state of ferrite.

As depicted on Fig. 3b, d, the microstructure is isotropic when starting with recrystallized ferrite, independent of the heating rate. The microstructures are quite similar: equiaxed ferrite grains and austenite phase at the recrystallized ferrite grain boundaries. However, the microstructure is nonisotropic, finer, and more heterogeneous when austenite is formed in non-recrystallized ferrite (Fig. 3c). This occurs only at high heating rates $\left(100{ }^{\circ} \mathrm{C}\right)$ when ferrite recrystallization and austenite formation overlap ("strong interaction").

The microstructural anisotropy resulting from the formation of austenite in a partially recrystallized ferrite observed in Fig. 3c remains even after long holding times as shown in Fig. 4. The microstructure exhibits very large ferrite grains elongated along the rolling direction. 

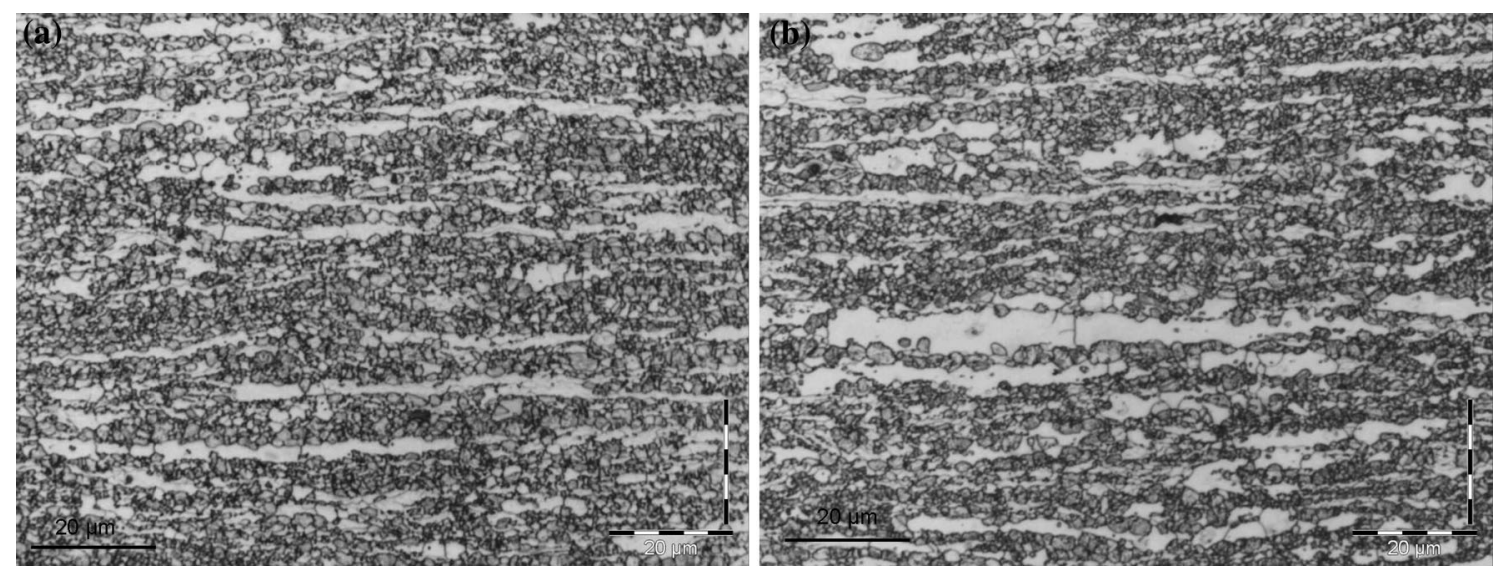

Fig. 4 Evolution of microstructures after a $1 \mathrm{~min}$ and b $10 \mathrm{~min}$ holding at $740{ }^{\circ} \mathrm{C}$ in the case of high heating rate

Strong interaction between austenite formation and ferrite recrystallization

In the following section, we will focus on the "strong interaction," i.e., on microstructural evolution associated with continuous heating at a constant rate of $100{ }^{\circ} \mathrm{C} / \mathrm{s}$, followed by subsequent soakings at $740{ }^{\circ} \mathrm{C}$. As shown previously, in these conditions, ferrite recrystallization and austenite formation overlap, and a competition between the two processes takes place.

\section{Recrystallization in transformation domain}

The evolution of the austenite, deformed, and recrystallized ferrite fractions (estimated from EBSD maps) is plotted as a function of annealing time at $740{ }^{\circ} \mathrm{C}$ in Fig. 5. The results show clearly that austenite formation is associated with a significant decrease of deformed ferrite fraction. As mentioned before, the deformed ferrite fraction at $720{ }^{\circ} \mathrm{C}$ (below Ac1) is $70 \%$. This value decreases to $31 \%$ at $740{ }^{\circ} \mathrm{C}-0$ min, while the recrystallized ferrite fraction remains almost constant. The same trend is observed during holding between 0 and $1 \mathrm{~min}$. The deformed ferrite fraction continues to decrease (10\% after $1 \mathrm{~min})$ during austenite formation, while recrystallized ferrite fraction remains constant (almost $29 \%$ ). Unexpectedly, between 1 and 10 min of annealing at $740{ }^{\circ} \mathrm{C}$, i.e., after completion of austenitic transformation, ferrite recrystallization still appears to be inhibited. After about $10 \mathrm{~min}$, ferrite recrystallization restarts, and the recrystallized ferrite fraction slowly increases at the expense of the deformed ferrite. Complete recrystallization finally requires about $1 \mathrm{~h}$. It is worthwhile to note that, as observed in preliminary experiments [24], complete recrystallization only takes place in 1 min at $680{ }^{\circ} \mathrm{C}$, a temperature, i.e., less than Ac1. There-fore, the kinetics of ferrite recrystallization is clearly slowed down after the completion of austenite transformation.

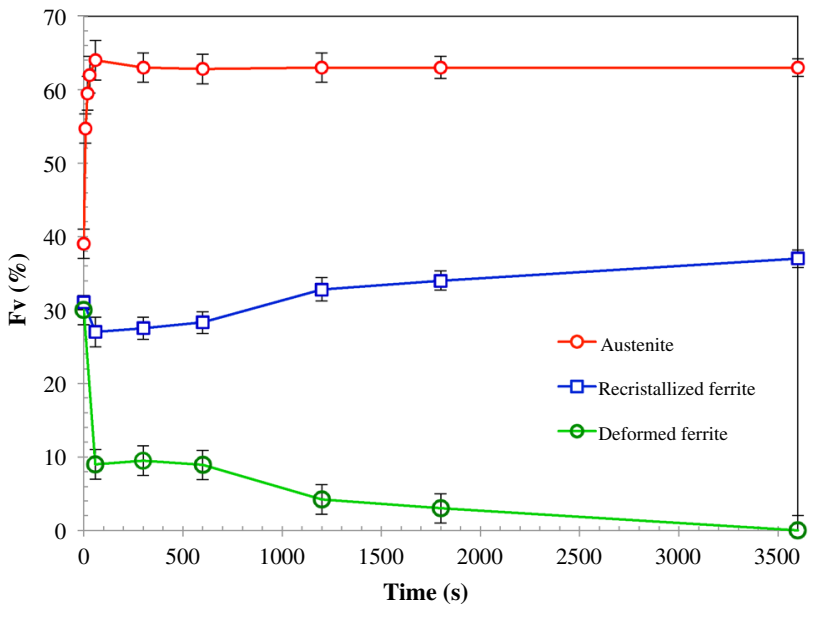

Fig. 5 Evolution of austenite, recrystallized and deformed ferrite fractions as a function of holding time at $740{ }^{\circ} \mathrm{C}$ for a given heating rate of $100{ }^{\circ} \mathrm{C} / \mathrm{s}$

\section{Influence of Mn segregation}

As Mn is well known to segregate in microbands [33], its relation to the microstructural constituents (austenite, deformed, and recrystallized ferrite) was investigated by EDS measurements. A representative measurement is shown on Fig. 6. The mean Mn concentration determined in the area is $1.4 \mathrm{wt} \%$, which is in good agreement with the nominal Mn content (1.5 wt\%). Figure 6a presents the microstructure observed by optical microscopy. The austenite (observed here as martensite) appears in dark gray, and is mainly organized in continuous and elongated bands along the rolling direction. The recrystallized and deformed ferrites, which appear in light gray, are mainly localized beside the austenite bands. Figure $6 \mathrm{~b}$ presents the Mn mapping on the corresponding area. It can be clearly seen that the austenite is mostly located in the Mn-rich bands, while the recrystallized and deformed ferrite match the Mn-poor interband areas. 


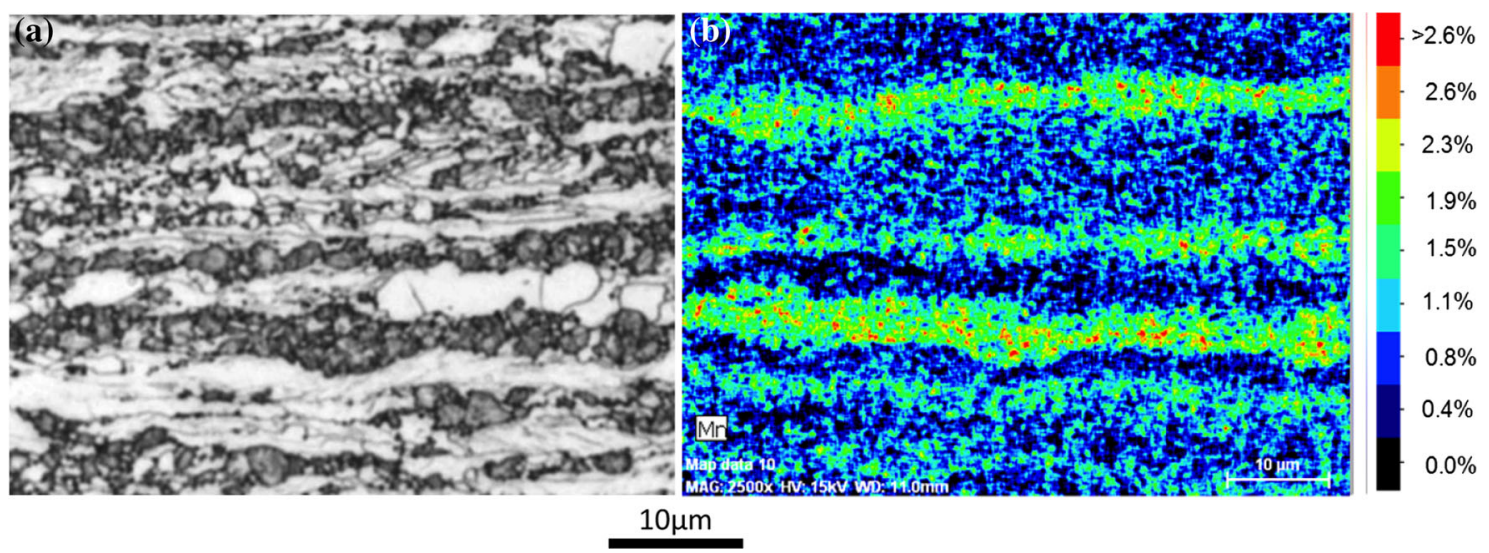

Fig. 6 a Microstructure after $740{ }^{\circ} \mathrm{C}-0 \mathrm{~min} / 100{ }^{\circ} \mathrm{C} / \mathrm{s}$ observed by optical microscopy and $\mathbf{b}$ corresponding EDS mapping showing the Mn distribution in $w t \%$

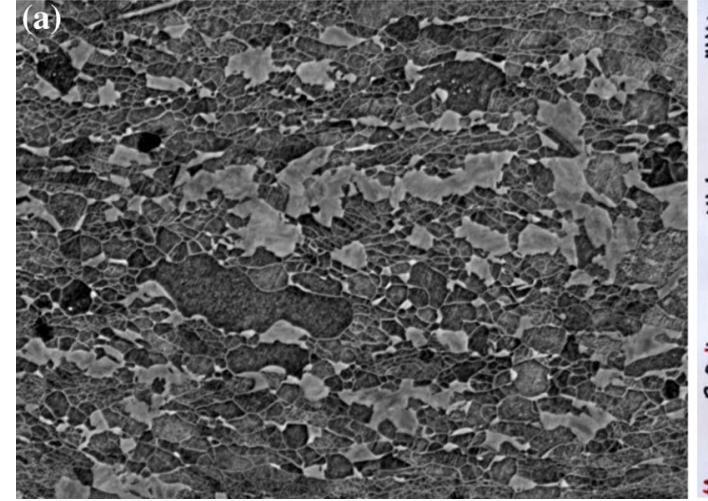

Fig. 7 a Microstructure after $740{ }^{\circ} \mathrm{C}-0 \mathrm{~min} / 100{ }^{\circ} \mathrm{C} / \mathrm{s}$ observed by SEM on back-scattered mode and $\mathbf{b}$ corresponding layer with the austenite/deformed ferrite interfaces (in black) and the austenite/

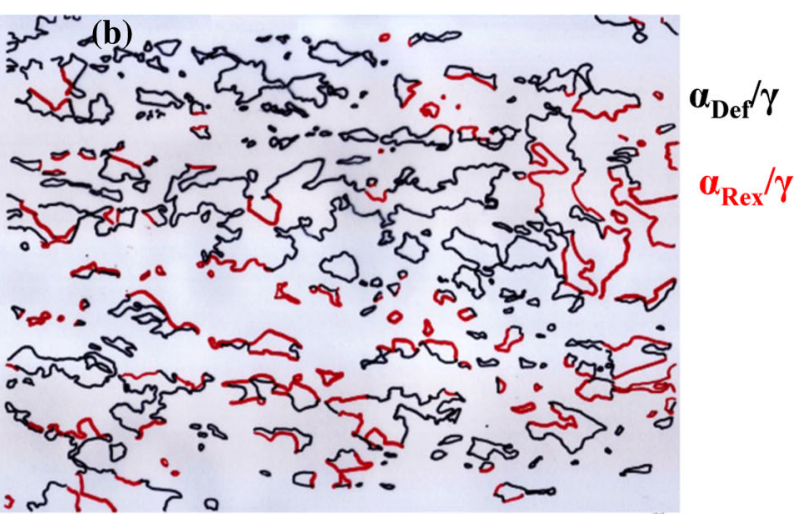

recrystallized ferrite interfaces (in red). The ratio of interface lengths between austenite/deformed ferrite and austenite/recrystallized ferrite was measured to be $3 \pm 1$ (Color figure online)

\section{Microstructure resulting from strong interactions}

The initial location of austenite islands at $740{ }^{\circ} \mathrm{C}-0 \mathrm{~min}$ has been determined by image analysis of ten SEM backscattered electron images. The technique offers sufficient contrast to distinguish between martensite, deformed ferrite, and recrystallized ferrite. The interfaces between these constituents were then outlined manually and the ratio of interface lengths per unit surface between austenite/ deformed ferrite and austenite/recrystallized ferrite was quantified (Fig. 7). At $\left(740{ }^{\circ} \mathrm{C}-0 \mathrm{~min}\right)$, the mean value of this ratio is $3 \pm 1$, meaning that austenite has three times more interface lengths with the deformed ferrite than with recrystallized ferrite. As reported in Fig. 5, the fractions of the recrystallized and deformed ferrites are similar at this step. Therefore, an interface ratio of 1 is expected if austenite is randomly distributed with respect to deformed and recrystallized ferrites. These observations support the hypothesis that austenite islands preferentially develop in the deformed ferrite regions.
A typical microstructure (heating rate at $100{ }^{\circ} \mathrm{C} / \mathrm{s}$ up to $740{ }^{\circ} \mathrm{C}$ and $1 \mathrm{~min}$ holding) resulting from the strong interaction between ferrite recrystallization and austenite transformation is shown in Fig. 8a. As already mentioned, these microstructures are composed of different grain populations, highlighted in different colors in Fig. 8a: austenite/martensite appears in red, deformed ferrite in green, equiaxed recrystallized ferrite in blue, and elongated recrystallized ferrite in gray.

The cumulated misorientation profiles plotted in Fig. 8b along the red and black lines in Fig. 8a clearly show that the elongated ferrite grains correspond to recrystallized ones. The misorientation is very low $\left(<1^{\circ}\right)$ in comparison with the profile in black corresponding to the deformed ferrite grain. The pronounced shape anisotropy of these grains is associated with Mn segregation (Fig. 6). The recrystallized ferrite develops in Mn-poor regions, while the austenite is located in Mn-rich regions. It is worth noting 
Fig. 8 a EBSD BC map of the microstructure heated at $100{ }^{\circ} \mathrm{C} / \mathrm{s}$ up to $740{ }^{\circ} \mathrm{C}$ then hold during 1 min. In red: martensite (austenite) grains. In green: deformed ferrite grains. In blue: equiaxed recrystallized ferrite grains. In gray: elongated recrystallized ferrite grains and b cumulated misorientation profiles measured in deformed and elongated ferrite grains (along the black and red line, respectively) (Color figure online)



that "deformed" grains (black profile in Fig. 8) can still be found after long soaking times. These grains appear to be polygonized by a recovery process. As a consequence, the progressive decrease of deformed ferrite detected between 10 and $60 \mathrm{~min}$ in Fig. 5 is probably due to both recrystallization and recovery.

\section{Discussion}

Kinetics of ferrite-to-austenite transformation

The sample with higher heating rate has a much higher volume fraction for a given annealing time. Another interesting result is that the maximum austenite volume fraction depends on heating rate (see Fig. 2). To our knowledge, this unusual behavior was first observed in $\mathrm{Fe}-$ $\mathrm{C}-\mathrm{Mn}-\mathrm{Si}$ and $\mathrm{Fe}-\mathrm{C}-\mathrm{Mn}-\mathrm{Mo}$ systems by Huang et al. [17]. However, some of our observations differ from those of their study. Increasing the heating rate does not result in a delay of austenite formation during heating. On the contrary, the volume fraction of austenite is much higher after continuous heating $\left(740{ }^{\circ} \mathrm{C}-0 \mathrm{~min}\right)$ at $100{ }^{\circ} \mathrm{C} / \mathrm{s}$ than at $1{ }^{\circ} \mathrm{C} / \mathrm{s}$.

However, the "acceleration effect" of heating rate on the kinetics of austenite formation has been reported in a few studies [34, 35]. These researchers mainly attribute such a behavior to the preservation of the defect structure in the non-recrystallized ferrite. This would provide additional nucleation sites for austenite and would enhance the growth rate of austenite [35]. These explanations are coherent and possible especially as our results show clearly that austenite islands preferentially develop in the deformed ferrite regions (see Fig. 7), and the decoupled experiments show that the presence of non-recrystallized ferrite contribute to enhance the austenite growth rate (see "Kinetics of austenite formation" section and Fig. 3).


Fig. 9 Isothermal section of the $\mathrm{Fe}-\mathrm{Mn}-\mathrm{C}$ at $740{ }^{\circ} \mathrm{C}$ calculated by THERMOCALC. The red dot represents the nominal composition, the dashed blue line represents the initial PE tie-line, and the dashed red line represents the initial LE tie-line (Color figure online)

However, we have shown that the kinetics of austenite growth also depends intrinsically on heating rate (see "Kinetics of austenite formation" section). In other words, the "acceleration effect" is partly not only due to the nonrecrystallization state but also due to the intrinsic effect of heating rate on the austenite formation.

Indeed, from a kinetic point of view and by analogy with ferrite transformation, it can be suspected that heating rate would influence the nature of LE at the $\alpha / \gamma$ interface. This equilibrium depends on the interaction between alloying elements and the migrating interface. Obviously, the position of tie-lines for austenite growth is affected by the chosen interfacial conditions (see Fig. 9). In what follows, the calculated interface velocities under PE and LE conditions at $740{ }^{\circ} \mathrm{C}$ for a heating rate of $100{ }^{\circ} \mathrm{C} / \mathrm{s}$ were compared to those measured. For calculations, the DICTRA program was used and a linear geometry is considered. 


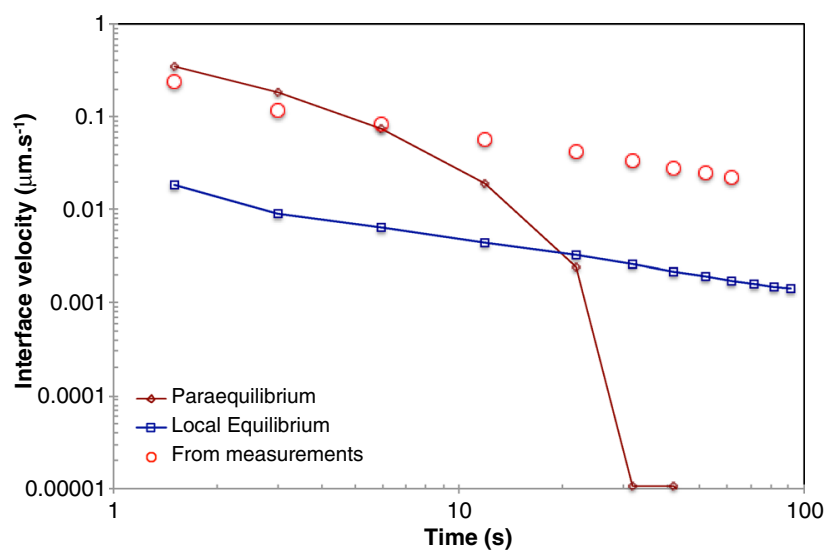

Fig. 10 Comparison between the measured ferrite/austenite interface velocity and those calculated under both local equilibrium and paraequilibrium conditions

The direct measurement of interface velocity is a tedious process. For the sake of simplicity, the mean interface velocity was evaluated from the measured evolution of austenite fraction using the following relation:

$v=L_{0} \frac{\mathrm{d} f_{\gamma}}{\mathrm{d} t}$,

where $f_{\gamma}$ is the measured austenite fraction, $L_{0}$ is the cell size (same as in the DICTRA calculations, $L_{0}=10 \mu \mathrm{m}$ ), and $v$ is the interface velocity. For reasons of consistency, the time step for both measured and calculated interface velocities was considered to be the same. The results are given in Fig. 10.

As expected early in the transformation, the calculated interface velocity under PE is higher than under LE one because the available driving force is higher. Furthermore, the comparison between calculations and measurements (Fig. 10) supports the assumption that austenite grows under a condition close to $\mathrm{PE}$ at the beginning of the transformation for high heating rates $\left(100{ }^{\circ} \mathrm{C} / \mathrm{s}\right)$. After $10 \mathrm{~s}$, the interface velocity under PE decreases drastically, and the difference between the measured interface velocity and that calculated under LE drops with time. It can be reasonably supposed that a continuous transition from the $\mathrm{PE}$ in the initial stage to the LE condition, at longer times, occurs. This unexpected behavior for ferrite-to-austenite transformation can be explained by the intrinsic properties of $\alpha / \gamma$ interface, analogous to ferrite transformation [3638]. At the beginning of austenite growth, the interface moves so fast that no LE can be established at the interface because not enough time is available for Mn redistribution. As a result, the local conditions are expected to be close to the PE ones, and the resulting kinetics is fast. This phenomenon takes place because both $\mathrm{C}$ and $\mathrm{Mn}$ diffusions occur during transformation, and their diffusivities differ substantially. It would be exacerbated at higher heating rate for two main reasons: first, the available driving force for austenite growth is enhanced. Indeed, at lower heating rate a substantial part of driving force is consumed before reaching holding temperature; and second, the presence of defects may accelerate both the $\mathrm{C}$ and Mn diffusions [39], especially as austenite develops preferentially in the deformed structure at high heating rate.

As a result, the nature of interface equilibrium depends on heating rate in $\mathrm{Fe}-\mathrm{C}-\mathrm{Mn}$ steel. This could explain partially why kinetics of austenite growth is faster and austenite fraction is higher at $100{ }^{\circ} \mathrm{C} / \mathrm{s}$ for a given annealing time.

For longer times, the interface motion becomes slower, and a LE can be reached at the ferrite/austenite interface since enough time is available for $\mathrm{Mn}$ redistribution through the interface. As a consequence, the presence of $\mathrm{Mn}$ and its behavior through the ferrite/austenite interface seem to play a key role.

To strengthen our arguments, some complementary experiments were conducted with the Fe- $0.15 \mathrm{wt} \% \mathrm{C}$ binary system using the same conditions as previously employed. The $\mathrm{Fe}-\mathrm{C}$ binary is a model system because the tieline for austenite growth depends only on temperature. In that case, a full LE is expected to apply at the ferrite/austenite interface. Figure 11 shows the time evolution of austenite volume fraction at $740{ }^{\circ} \mathrm{C}$ after slow or rapid heating (1 and $100{ }^{\circ} \mathrm{C} / \mathrm{s}$ ). In the $\mathrm{Fe}-\mathrm{C}$ binary system, the effects of heating rate on austenite evolution are different to those observed in the ternary $\mathrm{Fe}-\mathrm{C}-\mathrm{Mn}$ system. First, increasing the heating rate delays austenite formation. Indeed, contrary to the ternary $\mathrm{Fe}-\mathrm{C}-\mathrm{Mn}$ system, the mode for austenite growth is independent of the heating rate for the reason that a full equilibrium condition is applied at each time. As a consequence, the austenite fraction formed at the very beginning of annealing is lower at the higher heating rate because the initial volume fraction of austenite mostly depends on the time spent below the annealing temperature. Second, as expected in the $\mathrm{Fe}-\mathrm{C}$ system, the final equilibrium fraction of austenite does not depend on heating rate and corresponds to the equilibrium one as shown in Fig. 11.

As a partial conclusion, all the results and observations presented support the importance of the nature of the LE at the $\alpha / \gamma$ interface as a determining factor in the effects of heating rate on austenite kinetics in the $\mathrm{Fe}-\mathrm{C}-\mathrm{Mn}$ system. In particular, the interaction between manganese and the migrating interface seems to play a key role.

\section{Microstructural evolution}

It was shown that the interaction between ferrite recrystallization and austenite formation affects not only the kinetics of austenite formation but also the final 




Fig. 11 Kinetics of austenite growth in the Fe- $0.15 \mathrm{wt} \% \mathrm{C}$ system for heating rates of $1{ }^{\circ} \mathrm{C}$ and of $100{ }^{\circ} \mathrm{C} / \mathrm{s}$

microstructure. A strong interaction leads to anisotropic and heterogeneous microstructures. The anisotropy and heterogeneity have been unambiguously related to the presence of Mn-segregation bands in the material, originating from casting and subsequent rolling. Mn-rich bands are characterized by fine-grained microstructures with higher amount of austenite phase, whereas Mn-poor bands mostly show coarse, elongated ferrite grains. Most of these grains are recrystallized, but the presence of recovered grains was also evidenced (Fig. 8). This last observation may be related to a drastic slow down of the global ferrite recrystallization kinetics detected after the ferrite-to-austenite transformation (Fig. 5).

The link between high Mn concentration and high amount of austenite can be explained on the basis of both equilibrium and kinetics arguments. Manganese is a $\gamma$ stabilizer element, and thus higher equilibrium amounts of austenite are expected in $\mathrm{Mn}$-rich regions. In addition, Mnrich bands initially contain a higher amount of pearlite, resulting in a higher density of cementite particles after cold rolling. Since these particles act as nucleation sites for austenite, ferrite-to-austenite transformation is expected to be favored in Mn-rich regions. Furthermore, ferrite first recrystallizes in the Mn-poor bands because manganese hinders ferrite recrystallization. Indeed, the effect of solute addition such as $\mathrm{Mn}$ is known to delay the recrystallization probably due to a solute drag effect on migrating grain boundaries [40, 41].

However, these arguments are not sufficient to explain the development of microstructural anisotropy and grainsize heterogeneity. Indeed, although the lower heating rate used in the present study $\left(1{ }^{\circ} \mathrm{C} / \mathrm{s}\right)$ is not sufficient to reduce noticeably the $\mathrm{Mn}$ segregation before phase transformation starts, the microstructures obtained are isotropic and homogeneous. In the same way, neither heterogeneity nor anisotropy was observed in the case of samples slowly heated up to $\mathrm{Ac}_{1}$ and then rapidly heated in the transformation domain.

These observations suggest that the development of heterogeneous and anisotropic microstructures takes place not only in relation to Mn segregation, but is also due to the interaction between recrystallization and austenization. This may be explained as the consequence of complex mechanisms that are shown in the schematic in Fig. 12. During slow heating (Fig. 12a-d), complete ferrite recrystallization first takes place, which eliminates most crystal defects except grain boundaries. This phenomenon leads to a rather isotropic and homogeneous microstructure (see for instance Fig. 1b). It also probably results in a growth and partial redistribution of the cementite particles, with preferential pinning along new grain boundaries. Although austenite subsequently nucleates on both inter- and intragranular cementite particles, it is expected to grow preferentially along grain boundaries which act as much more efficient diffusion paths than along the matrix. Consequently, austenite progressively wets the ferrite boundaries, and then settles the grains by draining carbon over long distances. As a consequence, the final austenite/ferrite microstructure inherits the isotropy of the recrystallized ferrite, although some differences in local phase amounts may result from variations in Mn concentrations. This mechanism, related to "weak interactions," is consistent with many earlier studies [9-11] and was recently discussed in Ref. [17, 19].

In the case of rapid heating (Fig. 12e-h), some recrystallized ferrite grains develop before the nucleation of austenite, but most of the austenite transformation takes place in a few seconds in deformed ferrite grains. The analysis of the ratio of interface lengths between austenite/ deformed ferrite and austenite/recrystallized ferrite (Fig. 7) shows that austenite islands are mainly formed in the deformed ferrite regions and start to grow from there along the Mn-rich bands. The presence of defects in such a microstructure would stimulate the spheroidization of cementite lamellae [42], and the high heating rate would prevent subsequent coarsening. Therefore, more nucleation sites are available for the austenite. Furthermore, it is expected that austenite grows with comparable kinetics along ex- $\alpha$ grain boundaries and within the highly faulted grains. This will result in fine austenite grains developing more rapidly and preferentially along the Mn-rich bands through. It is worth noting that the diffusion through the defects may play a role on the resulting morphology of austenite since it was shown that a plane interface is unconditionally stable due to the favorable combination of the Gibbs-Thomson effect and of the concentration fields [43]. In the meantime, recrystallized ferrite grains continue to develop in competition with the austenite-rich bands, 


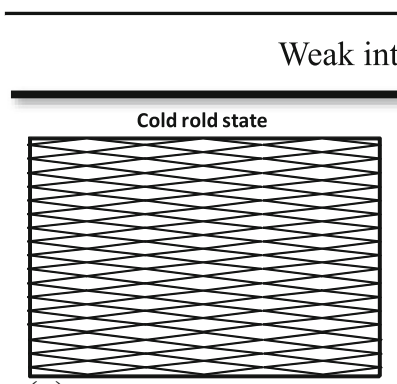

(a)

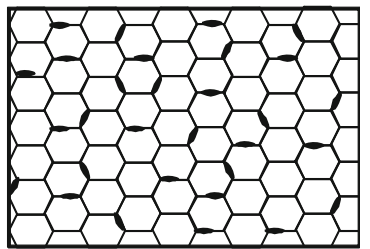

(c)

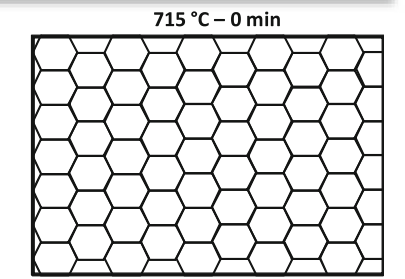

(b) $740^{\circ} \mathrm{C}-10 \mathrm{~min}$

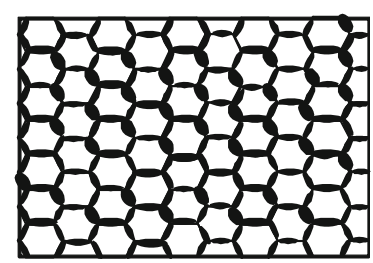

(d)



(e)

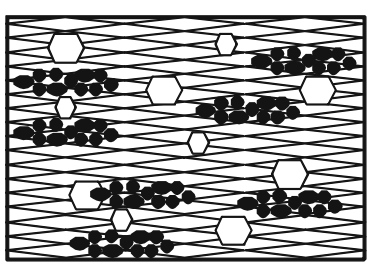

(g)

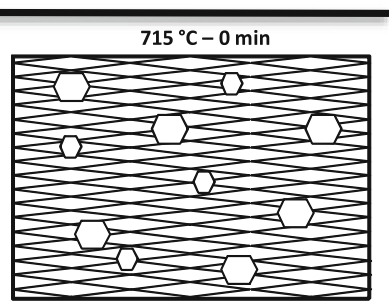

(f) $\quad 740^{\circ} \mathrm{C}-1 \mathrm{~min}$

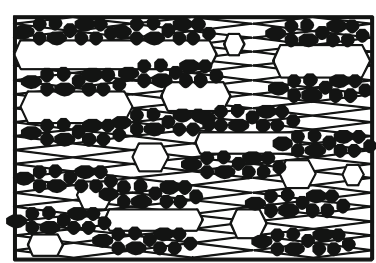

(h)

Fig. 12 Schematization of the recrystallization/transformation process associated with either slow heating (left) and rapid heating (right)

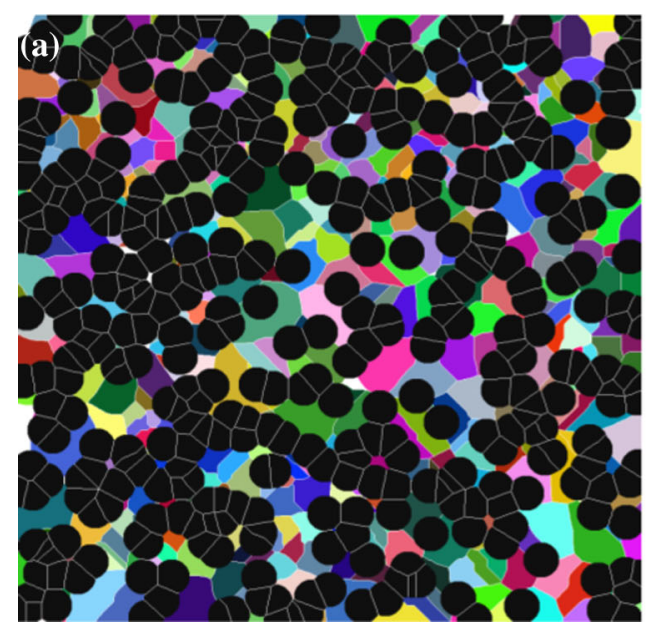

Fig. 13 Ferrite-austenite microstructures simulated with different sets of input parameters: a no influence of the Mn content on the nucleation densities of both austenite and recrystallized ferrite, same nucleation densities and growth rates for austenite and ferrite; b strong influence of $\mathrm{Mn}$ content on austenite nucleation density,

which finally results in strong anisotropic and heterogeneous microstructures. In other words, bands of fine austenite grains develop very rapidly, and then act as barriers for recrystallized ferrite grains which grow more slowly.

It is interesting to consider which conditions are required to generate a microstructure characterized by elongated ferrite grains. This was investigated using the program designed to generate $2 \mathrm{D}$ images. The main principles of this simulation were given in Part 2. It is described in more detail in ref. 29 where the influence of the different input parameters of the model on the final simulated structures was investigated. As examples, Fig. 13 shows two microstructures obtained with two sets

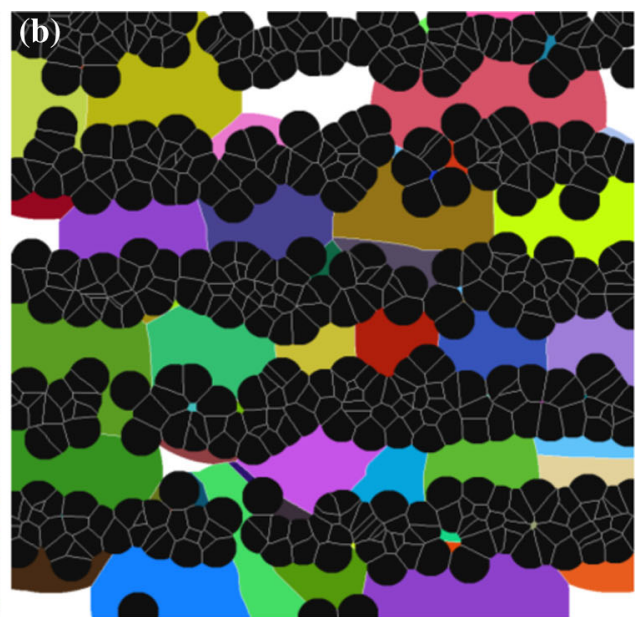

higher mean nucleation density and growth rate for austenite higher than for recrystallized ferrite. Black grains are austenite; white ones are deformed ferrite and colored ones are recrystallized ferrite (Color figure online)

of input parameters. Detailed analysis shows that three conditions are required to generate elongated ferrite grains: (i) nucleation of austenite must depend on the local content of manganese (influence of $\mathrm{Mn}$ on ferrite recrystallization appears to be of second order); (ii) recrystallized ferrite must have a lower nucleation density than austenite; and (iii) austenite must grow much faster than recrystallized ferrite, i.e., austenite must rapidly invade the material, long before the completion of recrystallization. These modeling conditions appear reasonable with regard to the experimental observations made in the present work.

The apparent inhibition of ferrite recrystallization subsequent to the ferrite-to-austenite transformation is an 
unexpected phenomenon that is more difficult to explain. Some deformed ferrite grains were still observed after several minutes of treatment in the two-phase domain, appearing to be stable against subsequent recrystallization or transformation. Their presence also contributes to the development of coarse anisotropic ferrite grains, since further recrystallization seems to occur only by growth of the already recrystallized ferrite grains rather than by nucleation of new ones. This suggests that phase transformation lowers the driving force for recrystallization nucleation. As this driving force is related to the level of internal energy density present in deformed grains, two explanations may explain this phenomenon: first, the austenite transformation may relax-at least partially-the elastic energy stored in remaining deformed ferrite grains. This relaxation may take place through the development of favorable orientations of new austenite grains (selection of crystal variants driven by local elastic stress field); second, growth of austenite is associated with carbon redistribution over long distances, which should proceed by diffusion along defects within deformed ferrite grains. This may contribute to stabilize them, i.e., to hinder recrystallization at the benefit of restoration. A paper published very recently gives some additional clarifications [44]. It is shown that, by a cellular automaton model, growth of recrystallized ferrite is topologically restricted, the moving $\gamma / \alpha$ interface can exert a pinning force on ferrite recrystallization, and nucleation of ferrite recrystallization could be inhibited through the elimination of its most favorable nucleation site. These effects would result in a slow recrystallization rate.

\section{Conclusion}

The present work gives some clarifications regarding the mechanisms of the interaction between ferrite recrystallization and austenite formation in high-strength $\mathrm{Fe}-\mathrm{C}-\mathrm{Mn}$ steels. It was shown from both experimental and modeling approaches and by using different heating paths that both ferrite recrystallization and austenite formation are strongly coupled and interdependent. The nature of the interaction (weak or strong) affects significantly the austenite formation, its spatial distribution, and the resulting morphology of microstructure. It was shown that the kinetics of austenite formation depends intrinsically on both the heating rate and recrystallization state of the ferrite. An unusual behavior of austenite growth was also seen at high heating rates. It is characterized by a much higher volume fraction of austenite for a given annealing time. Increasing heating rate does not result in a delay of austenite formation, and the maximum volume fraction of austenite remains high even at low temperature close to the eutectoid plateau. The theoretical analysis suggests that the interaction between manganese and ferrite/austenite migrating interface would play a key role in such evolutions. From a microstructural point of view, the initial austenite islands are mainly formed in the Mn-rich deformed ferrite regions, and it can be suspected that austenite growth is not isotropic, but directed preferentially toward the deformed regions. Furthermore, some elongated recrystallized ferrite grains were highlighted, and their pronounced shape anisotropy was associated with bands of Mn segregation. Unexpectedly, ferrite recrystallization still appears to be inhibited after completion of austenitic transformation, and complete recrystallization finally requires about $1 \mathrm{~h}$. Finally, a mechanism of microstructural formation was proposed and supported by $2 \mathrm{D}$ simulations.

\section{References}

1. Iung T, Azuma M, Bouaziz O et al (2003) A model for the prediction of microstructure and mechanical properties in cold rolled and annealed TRIP steels. Mater Sci Forum 426-432:3849-3854

2. Goune M, Maugis P, Drillet J (2012) A criterion for the change from fast to slow regime of cementite dissolution in $\mathrm{Fe}-\mathrm{C}-\mathrm{Mn}$ steels. J Mater Sci Technol 28:728-736

3. Arlazarov A, Goune M, Bouaziz O et al (2012) Evolution of microstructure and mechanical properties of medium Mn steels during double annealing. Mater Sci Eng A 542:31-39

4. Ågren J, Vassilev GP (1984) Computer simulations of cementite dissolution in austenite. Mater Sci Eng A 64:95-103

5. Ågren J, Abe H, Suzuki T, Sakuma Y (1986) The dissolution of cementite in a low-carbon steel during isothermal annealing at $700^{\circ} \mathrm{C}$. Metall Trans A 17:617-620

6. Hillert M, Nilsson K, Torndahl LE (1971) Effect of alloying elements on formation of austenite and dissolution of cementite. J Iron Steel Inst 209:49-66

7. Liu ZK, Agren J (1991) Morphology of cementite decomposition in an Fe-Cr-C alloys. Metall Trans A 22:1753-1759

8. Speich G, Demarest V, Miller R (1981) Formation of austenite during intercritical annealing of dual-phase steels. Metall Trans A 12:1419-1428

9. Garcia CI, Deardo AJ (1981) Formation of austenite in 1.5 pct Mn steels. Metall Trans A 12:521-530

10. Yang D, Brown E, Matlock D, Krauss G (1985) The formation of austenite at low intercritical annealing temperatures. Metall Trans A $16: 1523-1526$

11. Tokizane M, Matsumura N, Tsuzaki K et al (1982) Recrystallization and formation of austenite in deformed lath martensitic structure of low carbon steels. Metall Trans A 13:1379-1388

12. Elsesy I, Klaar H, Hussein A (1990) Effect of intercritical temperature and cold-deformation on the kinetics. Steel Res 61:131-135

13. Beswick J (1984) Effect of prior cold work on the martensitetransformation in SAE-52100. Metall Trans A 15:299-306

14. Mohanty RR, Girina OA, Fonstein NM (2011) Effect of heating rate on the austenite formation in low-carbon high-strength steels annealed in the intercritical region. Metall Mater Trans A 42A:3680-3690

15. Bleck W, Phiu-On K (2005) Microalloying of cold-formable multi phase steel grades. In: RodriguezIbabe JM, Gutierrez I, 
Lopez B, IzaMendia I (eds) Microalloying for new steel processes and applications. Trans Tech Publications Ltd, StafaZurich, pp 97-112

16. Hayami S, Furukawa T, Gondoh H, Takechi H (1979) Recent developments in formable hot and cold rolled HSLA including dual-phase sheet steels. In: Davenport AT (ed) Formable HSLA and dual-phase steels. TMS, New York, pp 167-180

17. Huang J, Poole WJ, Militzer M (2004) Austenite formation during intercritical annealing. Metall Mater Trans A 35A:3363-3375

18. Petrov R, Kestens L, Houbaert Y (2001) Recrystallization of a cold rolled trip-assisted steel during reheating for intercritical annealing. ISIJ Int 41:883-890

19. Azizi-Alizamini H, Militzer M, Poole WJ (2011) Formation of ultrafine grained dual phase steels through rapid heating. ISIJ Int 51:958-964

20. Maruyama N, Ogawa T, Takahashi M (2007) Recrystallisation at intercritical annealing in low carbon steels. In: Kang SJL, Huh MY, Hwang NM et al (eds) Recrystallization and grain growth III, pts 1 and 2. Trans Tech Publications Ltd, Stafa-Zurich, pp 247-252

21. Ogawa T, Maruyama N, Sugiura N, Yoshinaga N (2010) Incomplete recrystallization and subsequent microstructural evolution during intercritical annealing in cold-rolled low carbon steels. ISIJ Int 50:469-475

22. Peranio N, Li YJ, Roters F, Raabe D (2010) Microstructure and texture evolution in dual-phase steels: competition between recovery, recrystallization, and phase transformation. Mater Sci Eng A 527:4161-4168

23. Copyright ADCIS S.A. And Merinex Applied Imaging Aphelion

24. Internal report from ArcelorMittal

25. Kirkaldy J (1958) Diffusion in multicomponent metallic systems. 3. The motion of planar phase interfaces. Can J Phys 36:917-925

26. Coates D (1972) Diffusion-controlled precipitate growth in ternary-systems 1. Metall Trans A 3:1203-1212

27. Atkinson C, Akbay T, Reed RC (1995) Theory for reaustenitisation from ferrite/cementite mixtures in $\mathrm{Fe}-\mathrm{C}-\mathrm{X}$ steels. Acta Metall Mater 43:2013-2031

28. Purdy G, Ågren J, Borgenstam A et al (2011) ALEMI: a ten-year history of discussions of alloying-element interactions with migrating interfaces. Metall Mater Trans A 42:3703-3718

29. Hultgren A (1947) Isothermal transformation of austenite. Trans Am Soc Met 39:915-1005

30. Serra J (1982) Image analysis and mathematical morphology. Academic Press, New York
31. Krebs B, Germain L, Goune M, Hazotte A (2011) Banded structures in dual-phase steels-a novel characterization method. Int J Mater Res 102:200-207

32. Krebs B, Hazotte A, Germain L, Gouné M (2010) Quantitative analysis of banded structures in dual-phase steels. Image Anal Stereol 29:85-90

33. Krebs B, Germain L, Hazotte A, Gouné M (2011) Banded structure in dual phase steels in relation with the austenite-toferrite transformation mechanisms. J Mater Sci. doi:10.1007/ s10853-011-5671-9

34. Andrade-Carozzo V, Jacques PJ (2007) Interactions between recrystallisation and phase transformations during annealing of cold rolled Nb-added TRIP-aided steels. Mater Sci Forum 539-543:4649-4654

35. Kulakov M, Poole WJ, Militzer M (2013) The effect of the initial microstructure on recrystallization and austenite formation in a DP600 steel. Metall Mater Trans A 44:3564-3576

36. Hutchinson CR, Fuchsmann A, Brechet Y (2004) The diffusional formation of ferrite from austenite in $\mathrm{Fe}-\mathrm{C}-\mathrm{Ni}$ alloys. Metall Mater Trans A 35A:1211-1221

37. Purdy G, Ågren J, Borgenstam A, Bréchet Y, Enomoto M, Furuhara T, Gamsjager E, Gouné M, Hillert M, Hutchinson C, Militzer M, Zurob H (2011) ALEMI: a ten-year history of discussions of alloying-element interactions with migrating interfaces. Metall Mater Trans A 42(2011):3703-3718

38. Viardin A (2009) Modélisation par champ de phases de la croissance de la ferrite allotriomorphe dans les aciers $\mathrm{Fe}-\mathrm{C}-\mathrm{Mn}$. Institut National Polytechnique de Lorraine, Nancy

39. Pussegoda N, Tyson W, Wycliffe P, Purdy G (1984) Segregation of manganese during intercritical annealing of dual phase steels. Metall Mater Trans A 15:1499-1502

40. Hu H, Goodman S (1970) Effect of manganese on annealing texture and strain ratio of low-carbon steels. Metall Trans 1:3057-3064

41. Leslie W, Plecity F, Michalak J (1961) Recrystallization of iron and iron-manganese alloys. Trans Metall Soc AIME 221:691-700

42. Tian Y, Kraft R (1987) Mechanisms of pearlite spheroidization. Metall Trans A 18:1403-1414

43. Appolaire B, Gouné M (2006) Linear stability analysis of a $\gamma^{\prime}$ $\mathrm{Fe} 4 \mathrm{~N}$ nitride layer growing in pure iron. Comput Mater Sci 38:126-135

44. Zheng C, Raabe D (2013) Interaction between recrystallization and phase transformation during intercritical annealing in a coldrolled dual-phase steel: a cellular automaton model. Acta Mater 61:5504-5517 